Article

\title{
Anti-Inflammatory Effects of Adenine Enhance Osteogenesis in the Osteoblast-Like MG-63 Cells
}

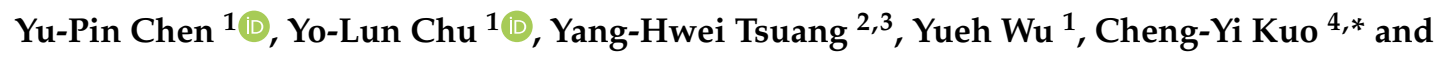 \\ Yi-Jie Kuo 1,3,* \\ 1 Department of Orthopedic Surgery, Wan Fang Hospital, Taipei Medical University, Taipei 11696, Taiwan; \\ 99231@w.tmu.edu.tw (Y.-P.C.); adslme123@gmail.com (Y.-L.C.); birdywithlove@hotmail.com (Y.W.) \\ 2 Department of Orthopedic Surgery, Shuang Ho Hospital, Taipei Medical University, New Taipei 23561, \\ Taiwan; tsuangyh@gmail.com \\ 3 Department of Orthopedic Surgery, School of Medicine, College of Medicine, Taipei Medical University, \\ Taipei 11031, Taiwan \\ 4 Department and Graduate Institute of Biology and Anatomy, National Defense Medical Center, \\ Taipei 11490, Taiwan \\ * Correspondence: kchengyi@gmail.com (C.-Y.K.); kyj.tmu@gmail.com (Y.-J.K.)
}

Received: 31 May 2020; Accepted: 17 July 2020; Published: 19 July 2020

\begin{abstract}
Background: Adenine is a purine with a role in cellular respiration and protein synthesis. It is considered for its pharmacological potential. We investigated whether anti-inflammatory effect of adenine benefits on the proliferation and maturation of osteoblastic cells. Methods: Human osteoblast-like cells (MG-63) were cultured with adenine under control conditions or pre-treated with $10 \mathrm{ng} / \mathrm{mL}$ of tumor necrosis factor- $\alpha$ (TNF- $\alpha$ ) followed by adenine treatment. Cell viability was examined using dimethylthiazol diphenyltetrazolium bromide (MTT) assay. Expression of cytokines and osteogenic markers were analyzed using quantitative PCR (qPCR) and ELISA. Enzyme activity of alkaline phosphatase (ALP) and collagen content were measured. Results: TNF- $\alpha$ exposure led to a decreased viability of osteoblastic cells. Treatment with adenine suppressed TNF- $\alpha$-induced elevation in IL-6 expression and nitrite oxide production in MG-63 cells. Adenine induced the osteoblast differentiation with increased transcript levels of collage and increased ALP enzyme activity. Conclusions: Adenine exerts anti-inflammatory activity in an inflammatory cell model. Adenine benefits osteoblast differentiation in normal and inflammatory experimental settings. Adenine has a potential for the use to treat inflammatory bone condition such as osteoporosis.
\end{abstract}

Keywords: adenine; IL-6; osteogenesis; osteoblast; inflammatory bone disease

\section{Background}

Osteoporosis is a common bone disease, which is characterized by poor bone strength and bone loss. It contributes to bone fragility and in turn fracture. Osteoporosis affects an estimated 75 million people in Europe, USA and Japan and causes more than approximately 9 million fractures worldwide every year [1,2]. It is prevalent in postmenopausal women, attributable to estrogen deficiency-related imbalanced bone resorption. Osteoporosis has a remarkable social and economic cost with a projected increase rate of $25 \%$ [3-5]. Clinically available treatments for osteoporosis include use of anti-resorption agents, such as bisphosphonates and hormone replacement therapy [6]. Despite the clinical benefits of the treatments, they still have a host of possible adverse effects [7,8]. Recently, the role of inflammation in bone remodeling has gained much attention. Pathogenesis of osteoporosis is multifactorial which involves inflammation [9]. Pro-inflammatory cytokines, such as primarily TNF- $\alpha$ and interleukin (IL)-6, are known to contribute to bone resorption and impaired bone remodeling, leading to deteriorated 
bone architecture [10-13]. In postmenopausal osteoporosis, deficient estrogen activates T-cells to produce an excessive amount of TNF- $\alpha$ and in turn inhibits osteoblast activity [14]. Previous studies have indicated an inhibitory effect of TNF- $\alpha$ on osteoblast differentiation $[15,16]$. TNF- $\alpha$ has inhibited levels of bone matrix components such as collagens and alkaline phosphatase [16,17]. A variety of agents with anti-inflammatory property have been demonstrated to have therapeutic benefits to osteoporosis [16,18-21]. In addition to synthetic agents, it is of interest to scientifically explore and examine food ingredients that facilitate bone homeostasis without adverse effects in a setting of osteoporosis.

Adenine is a purine base that is found in DNA and RNA. It is synthesized in the liver in human and found in a variety of foods, such as brewer's yeast. Biological compounds containing adenine base include DNA in protein synthesis, nicotinamide adenine dinucleotide (NAD) and flavin adenine dinucleotide (FAD) in metabolism, adenosine triphosphate (ATP) in cellular respiration. In addition, recent studies have reported pharmacological potential of adenine. Adenine has been shown to attenuate allergic responses [22,23]. It has been reported to exert anti-inflammatory activity in different experimental settings [24,25]. Adenine is shown to protect cells from hostile conditions including rat Purkinje cells and erythrocyte in whole blood [26-28]. It is of interest to investigate the pharmacological effects of adenine on the proliferation and maturation of osteoblasts in osteoporosis in aspect of inflammation that contributes primarily to the bone disorder.

In this study, we examined the pharmacological activity of adenine in bone metabolism with emphasis on cytokine-induced inflammation. Modulation of pro-inflammation in TNF- $\alpha$ treated osteoblast-like cells was determined. Osteoblasts are known to synthesize and secrete several components of bone matrix, mainly alkaline phosphatase (ALP), osteocalcin and collagens, while osteoclasts are involved in bone resorption. Regulation of bone metabolism-related gene expression mediated by adenine in TNF- $\alpha$ treated osteoblast was evaluated, including ALP and collagen type I, whichare two bone matrix components synthesized and secreted by osteoblasts.

\section{Results}

\subsection{Effects of Adenine on Viability of Osteoblast-Like MG-63 Cells}

To examine the influence of adenine on growth of osteoblasts, MG-63 cells were treated with serial concentrations of adenine $(0-250 \mu \mathrm{M})$ in presence or absence of TNF- $\alpha$ for $24 \mathrm{~h}$ and the cell viability was evaluated using MTT assay. The results showed that adenine had no cytotoxicity on the growth of MG-63 cells (Figure 1A). Adenine had no significant influence on the slightly decreased viability of MG-63 cells exposed to TNF- $\alpha$ (10 ng/mL) (Figure 1B).

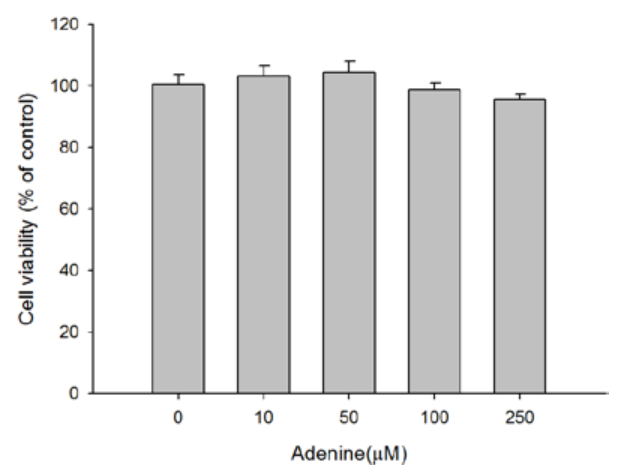

(A)

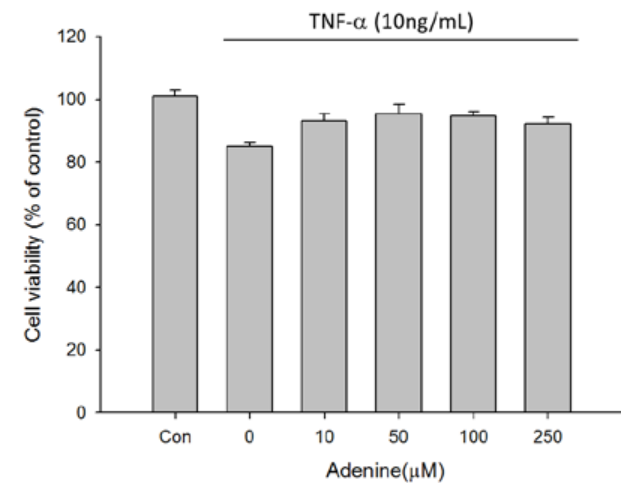

(B)

Figure 1. Effects of adenine on cell proliferation of MG-63 cells. (A) MG-63 cells were exposed to serial concentrations of adenine $(0-250 \mu \mathrm{M} / \mathrm{mL})$ for $24 \mathrm{~h}$. (B) MG-63 cells were pre-cultured with TNF- $\alpha$ $(10 \mathrm{ng} / \mathrm{mL})$ and treated with serial concentrations of adenine $(0-250 \mu \mathrm{M})$ for $24 \mathrm{~h}$. Cell viability was determined using MTT assay. Data were expressed as mean \pm SD. 


\subsection{Adenine Ameliorated TNF- $\alpha$-Induced IL-6 Production in Osteoblast-Like MG-63 Cells}

We next evaluated immunomodulatory effects of adenine on production of IL-6 in osteoblast-like cells upon stimulation of TNF- $\alpha$. A low baseline expression of IL- 6 was detected in the supernatant of untreated MG-63 cell culture. Adenine treatment dose-dependently decreased baseline IL-6 level in MG-63 cells (Figure 2A). Exposure to TNF- $\alpha$ led to a 10-fold increase in IL-6 production in MG-63 cells (Figure 2B). The TNF- $\alpha$ - induced elevation of IL-6 production was reduced in response to adenine treatment in MG-63 cells. We also investigated the influence of adenine on expression of inducible nitric oxide synthase (iNOS) that is upregulated by TNF- $\alpha$ in osteoblasts. The results showed that expression of iNOS was stimulated 2-fold by TNF- $\alpha$, whereas adenine had no influence on naïve MG-63 cells (Figure 2C). Increases of iNOS expression were inhibited by adenine in dose-dependent manner (Figure 2D). The data of nitrite production in MG-63 cells supported the finding of reduction in iNOS expression elevated by TNF- $\alpha$ (Figure 2E,F).

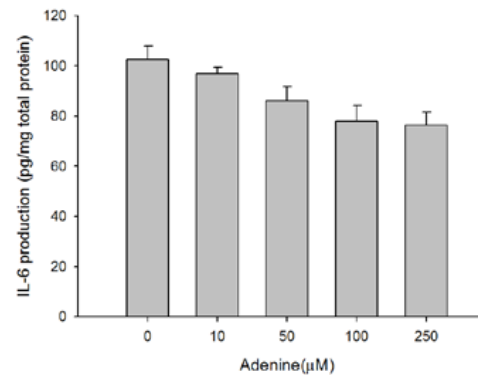

(A)

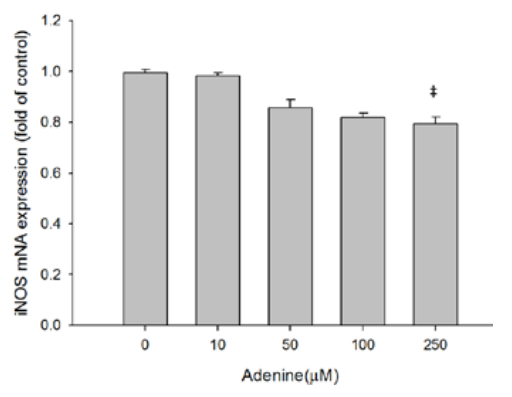

(C)

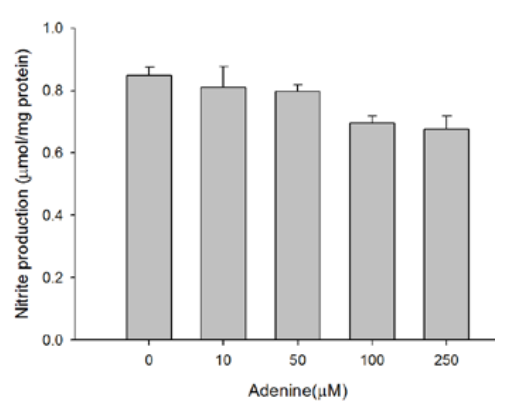

(E)

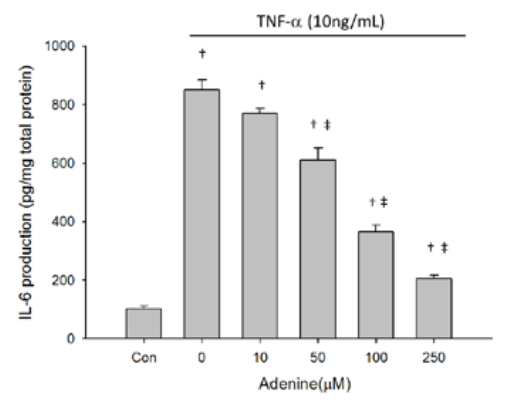

(B)

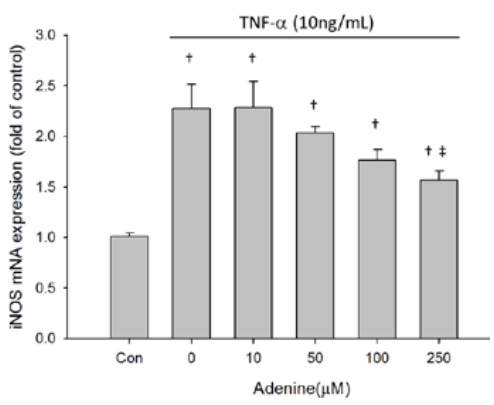

(D)

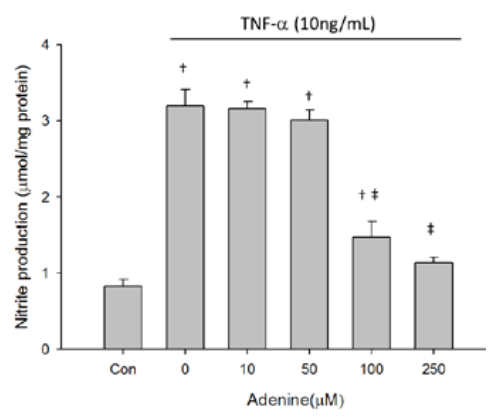

(F)

Figure 2. Effect of adenine on pro-inflammatory response in MG-63 cells. Cells were treated with or without $10 \mathrm{ng} / \mathrm{mL}$ of TNF- $\alpha$ and cultured with serial concentrations of adenine $(0-250 \mu \mathrm{M})$ for $24 \mathrm{~h}$. (A,B) IL-6 production were determined by ELISA. (C,D) mRNA expression of iNOS upon TNF- $\alpha$ stimulation was examined using qPCR. (E,F) Nitrite production in culture medium of MG-63 stimulated with or without TNF- $\alpha$ was evaluated. Data were expressed as mean \pm SD. $\ddagger, p<0.05$ as comparing to $0 \mu \mathrm{g} / \mathrm{mL} ;+, p<0.05$ as comparing to control (Con). 


\subsection{Effects of Adenine on MG-63 Differentiation}

As adenine treatment slightly restored inhibited proliferation of TNF- $\alpha$-treated MG-63 cells, we next investigated whether adenine had effects on osteoblast differentiation by measuring expression and enzyme activity of ALP that is involved in osteoblast maturation. The results revealed that enzyme activity of ALP in MG-63 cells was increased by adenine treatment in a dose-dependent manner (Figure 3A). Exposure of MG-63 cells to TNF- $\alpha$ resulted in a significantly reduced ALP activity and the decrease of ALP activity was restored by adenine (Figure 3B). Adenine treatment led to increased mRNA expression of ALP and restored the reduced ALP expression in TNF- $\alpha$-treated MG- 63 cells (Figure 4A,B). In addition to ALP activity, we next evaluated the effects of adenine on collagenogenesis, which is an essential event in the differentiation of osteoblast. The results showed that adenine treatment increased the production of collagen type I in MG-63 cells at a concentration of $10 \mu \mathrm{g} / \mathrm{mL}$ (Figure 5A). TNF- $\alpha$ treatment $(10 \mathrm{ng} / \mathrm{mL}$ ) inhibited the production of collagen type I in MG-63 cells $(\mathrm{p}<0.05)$ and the reduction was restored in response to adenine treatment in a dose-dependent manner (Figure 5B). Moreover, collagen level was upregulated in adenine-treated MG-63 cells at a concentration of $10 \mu \mathrm{g} / \mathrm{mL}$ (Figure 6A). Declined mRNA expression of collagen in TNF- $\alpha$-treated MG-63 cells was restored sharing a similar pattern with that of protein synthesis (Figure $6 \mathrm{~B}$ ).

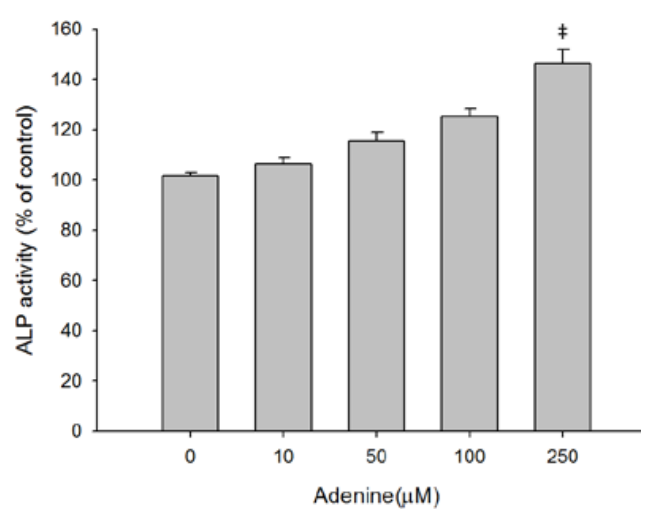

(A)

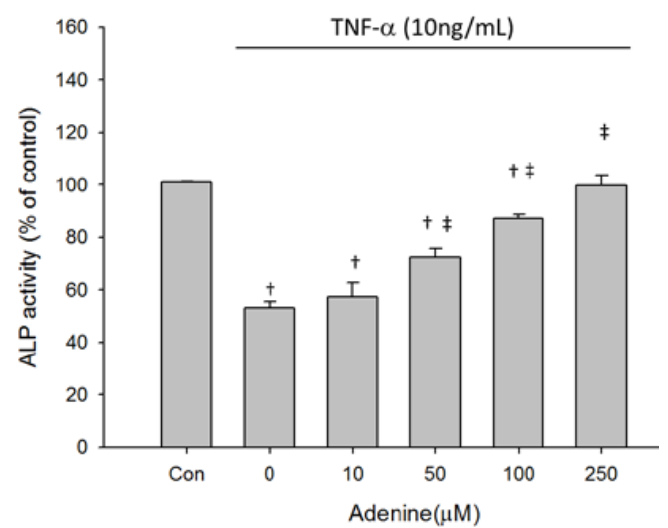

(B)

Figure 3. Adenine induced alkaline phosphatase (ALP) activity in MG-63 cells treated without (A) or with (B) stimulation of TNF- $\alpha$. Cells were treated with serial concentrations of adenine $(0-250 \mu \mathrm{M})$ for $24 \mathrm{~h}$. Data were expressed as mean \pm SD. $\ddagger, p<0.05$ as comparing to $0 \mu \mathrm{g} / \mathrm{mL} ;, t p<0.05$ as comparing to control (Con).

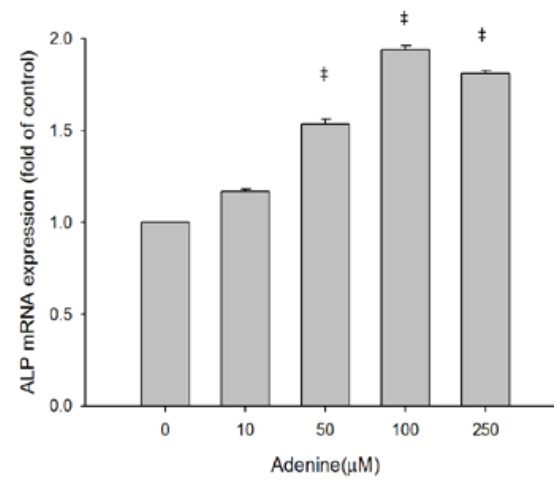

(A)

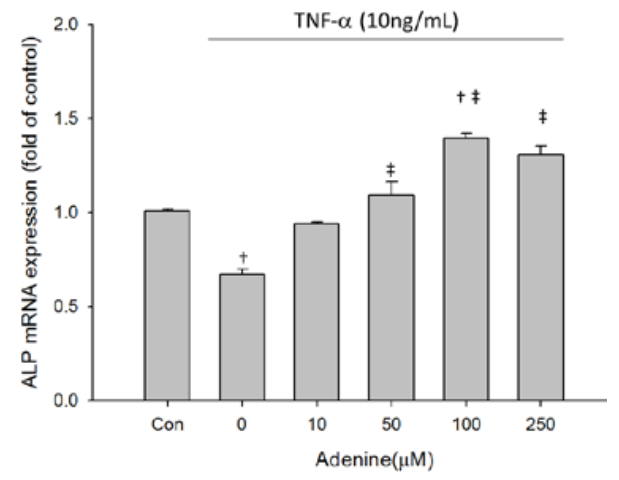

(B)

Figure 4. Adenine increased ALP mRNA expression in MG-63 cells treated without (A) or with (B) TNF- $\alpha$. Cells were treated with serial concentrations of adenine $(0-250 \mu \mathrm{M})$ for $24 \mathrm{~h}$ and mRNA expressions were determined by qPCR. Data were expressed as mean \pm SD. $\ddagger, p<0.05$ as comparing to $0 \mu \mathrm{g} / \mathrm{mL} ;+, p<0.05$ as comparing to control (Con). 


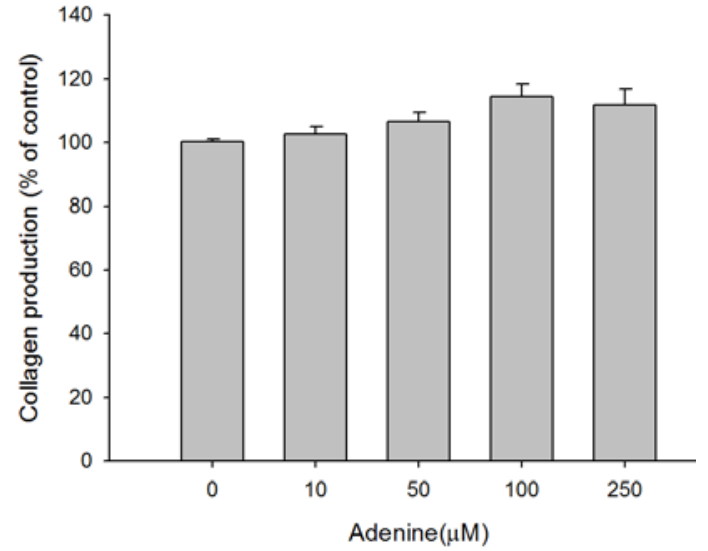

(A)

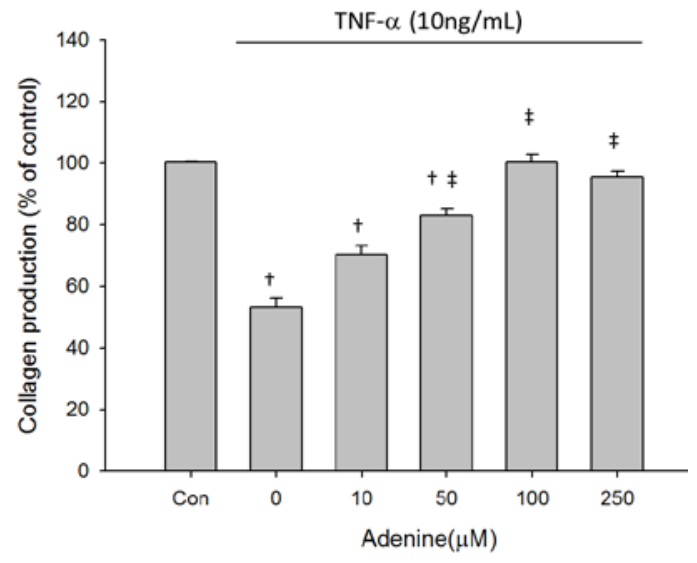

(B)

Figure 5. Effect of adenine on collagen synthesis in MG-63 cells treated without (A) or with (B) stimulation of TNF- $\alpha$. Cells were treated with serial concentrations of adenine $(0-250 \mu \mathrm{M})$ for $24 \mathrm{~h}$ and collagen synthesis in MG-63 cells was determined by ELISA. Data were expressed as mean \pm SD. $\ddagger, p<0.05$ as comparing to $0 \mu \mathrm{g} / \mathrm{mL} ; \dagger, p<0.05$ as comparing to control (Con).

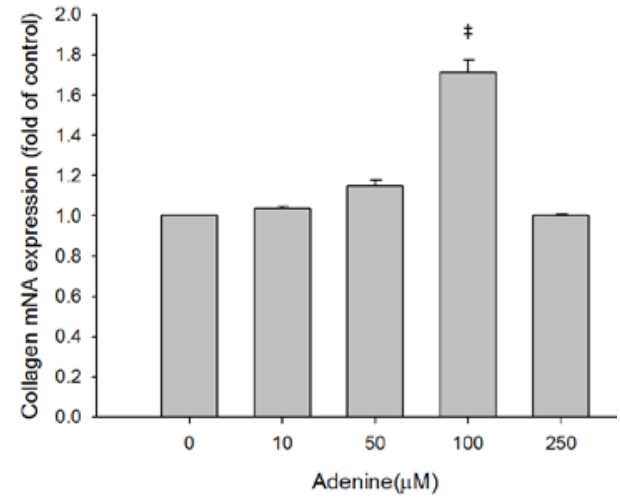

(A)

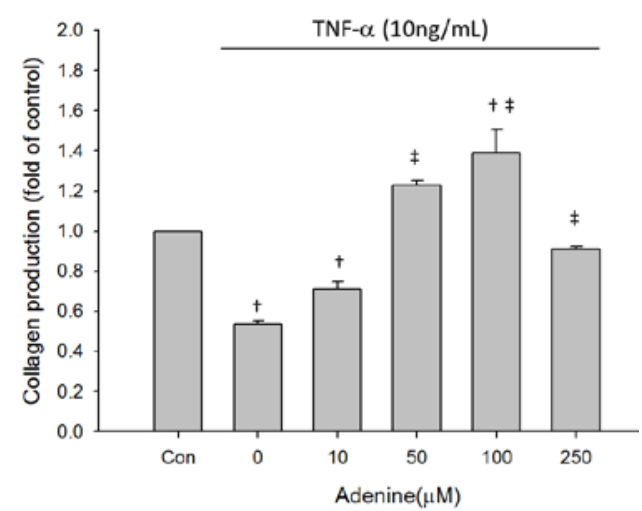

(B)

Figure 6. Adenine induced collagen type I mRNA expression in MG-63 cells treated without (A) or with (B) stimulation of TNF- $\alpha$. Cells were treated with serial concentrations of adenine $(0-250 \mu \mathrm{M})$ for $24 \mathrm{~h}$ and mRNA expressions were determined by qPCR. Data were expressed as mean $\pm \mathrm{SD} . \ddagger, p<0.05$ as comparing to $0 \mu \mathrm{g} / \mathrm{mL} ;+, p<0.05$ as comparing to control (Con).

\section{Discussion}

In this study, we studied the anti-inflammatory activity of adenine with emphasis on the proliferation and differentiation of osteoblast. We found that adenine exhibited favorable anti-inflammatory activity on TNF- $\alpha$-induced productions of IL-6 and NO in MG-63 cells. Our data revealed that adenine benefited differentiation of osteoblast, with evidence of an elevated ALP activity and collagen levels. The anti-inflammatory effect of adenine is suggested to reduce deterioration in osteogenesis.

Osteoporosis characterized by deterioration in bone structure is considered as low chronic inflammatory disease. Several pro-inflammatory cytokines have been reported to deteriorating bone architecture in turn, including TNF- $\alpha$ and IL-6 [11,29-31]. TNF- $\alpha$ has been shown to stimulate IL-6 secretion in osteoblastic cells, which acts in turn on osteoclasts and bone resorption [32,33]. Clinical findings are suggestive of the role of IL-6 in pathologic bone resorption [34,35]. Anti-TNF- $\alpha$ treatment has been demonstrated to improve inflammatory-induced bone loss through reducing IL-6 production [36-38]. In this study, we found that adenine exhibited anti-inflammatory activity, showing suppression of TNF- $\alpha$-induced IL-6 production in osteoblastic cells. A decreasing trend of IL-6 
expression was correlated with increases in cell viability of MG-63 cells. The finding is consistent with the results of previous studies reporting the effects of TNF- $\alpha$ on proliferation of osteoblastic cells $[16,33]$. In addition to IL-6, TNF- $\alpha$ induces expression of iNOS, leading to excessive NO production and in turn cytotoxicity in osteoblastic cells [39-41]. We reported that adenine repressed TNF- $\alpha$-induced inflammatory phenomenon in osteoblast-like cells by inhibiting iNOS expression. Suppression of NO production by adenine treatment was associated with restoration of cell viability disturbed in presence of TNF- $\alpha$. Given the findings, it is suggested that adenine contributes to proliferation of osteoblastic cell through anti-inflammatory actions in the current experimental setting.

Osteoblast differentiation is divided into three stages: cell proliferation, matrix maturation and mineralization [42]. ALP is expressed in osteoblast cells and considered as a marker for their early differentiation [43]. We showed that adenine treatment increased ALP expression and activity in MG-63 cells, suggesting that adenine benefits the differentiation of osteoblasts in the early stage. In TNF- $\alpha$-stimulated MG-63 cells, treatment with adenine restored the reduced ALP expression and activity. The finding implies the beneficial potency of adenine for inflammatory bone disease. Collagen is mainly produced by osteoblast in bone maturation [44-46]. We showed that adenine increased collagen synthesis and collagen content in MG-63 cells. Reduction of collagen production by TNF- $\alpha$ was restored by adenine treatment, suggesting that adenine potentially benefits maturation of osteoblast cells. The findings reveal the adenine potentially stimulates the osteoblastic differentiation and the potency to enhance ALP activity and collagenogenesis.

We demonstrated that adenine exhibits anti-inflammatory activity and in turn contributes to the differentiation of osteoblast cells. It is suggested that adenine has beneficial effects on osteoporotic condition via partial restoration of bone matrix components. More studies are required to reveal the underlying mechanism by which adenine benefits the differentiation and maturation of osteoblasts.

\section{Materials and Methods}

\subsection{Cell Culture}

Human osteoblast-like MG-63 cells (ATCC ${ }^{\circledR}$ CRL-1427'TM, Rockville, MD, USA) were cultured in Dulbecco's modified Eagle's medium (DMEM, Sigma, St. Louis, MO, USA) supplemented with $10 \%$ fetal bovine serum (FBS, Gibco, Carlsbad, CA, USA) and $100 \mu \mathrm{g} / \mathrm{mL}$ penicillin/streptomycin (all Sigma, St. Louis, MO, USA) at $37^{\circ} \mathrm{C} .6 \times 10^{5}$ cells were seeded in a 6-well culture plate and grown until $80 \%$ confluence. For treatments with adenine (Sigma), TNF- $\alpha$-treated MG-63 cell model was prepared as previously described [16]. In brief, cells were pretreated with TNF- $\alpha(10 \mathrm{ng} / \mathrm{mL})$ in $1 \%$ FBS DMEM for $16 \mathrm{~h}$ followed by incubation with adenine with serial concentrations in serum-free DMEM for $24 \mathrm{~h}$. After treatments, resulting cells were washed with phosphate-buffered saline (PBS; $\mathrm{pH}$ 7.2) and collected for following analyses. The control group was MG-63 cells without any treatment.

\subsection{Cell Viability Assay}

Cell viability was measured using MTT assay. Cells were treated with TNF- $\alpha$ and/or adenine, followed by an incubation with (3-(4,5-Dimethylthiazol-2-yl)-2,5-Diphenyltetrazolium Bromide) $(0.5 \mathrm{mg} / \mathrm{mL})$ at $37^{\circ} \mathrm{C}$ for $4 \mathrm{~h}$. The number of viable cells was directly proportional to the production of formazan determined by measuring the absorbance at $570 \mathrm{~nm}$.

\subsection{Alkaline Phosphatase Activity Assay}

$1 \times 10^{5}$ of cells were seeded for each well of 24-well plates and incubated for 16-20 h, followed by exposure to adenine at various concentrations for $72 \mathrm{hr}$. After removing medium, remaining cells were lysed by freeze-thaw method and centrifuged at $15,000 \times \mathrm{g}, 4{ }^{\circ} \mathrm{C}$ for $5 \mathrm{~min}$. The resulting supernatant was subject to ALP activity assay. $20 \mu \mathrm{L}$ of cell lysate was mixed with $100 \mu \mathrm{L}$ Tris-glycine buffer ( $\mathrm{pH}$ 10.3) and $100 \mu \mathrm{L}$ of p-nitrophenyl phosphate (Sigma), followed by incubation at $37^{\circ} \mathrm{C}$ 
for $30 \mathrm{~min}$ and adding $50 \mu \mathrm{L}$ of $3 \mathrm{M} \mathrm{NaOH}$. An absorbance reading of $405 \mathrm{~nm}$ was performed using microplate reader.

\subsection{RNA Extraction, RT-PCR and Quantitative PCR ( $q P C R)$}

Total RNA of cell after treatments was extracted using Trizol (Sigma, Milpitas, CA, USA), according to the manufacturer's protocol. mRNA levels were measured by qPCR amplification with designed primer pairs listed in Table 1 using the ABI PRISM 7700 sequence detection system (Applied Biosystems, Foster City, CA, USA). For mRNA quantitation, FastStart Universal SYBR Green Master (Roche Applied Science, Penzberg, Germany) was used. The threshold cycle numbers were calculated using the $\Delta \Delta C T$ relative value method and normalized to $\beta$-actin. Each qPCR reaction was repeated at least three times.

Table 1. Primers used in the PCR.

\begin{tabular}{ccc}
\hline IL-6 & 5'-TAGCCCTGAGAAAGGAGACATG-3' & 5'-AGGCAAGTCTCCTCATTGAATC-3' $^{\prime}$ \\
\hline iNOS & 5'-GCGGAGCGATGGGAAGCATG-3' $^{\prime}$ & 5'-CCCGAGCTCCTGGAACCAC-3' $^{\prime}$ \\
Alkaline phosphatase & 5'-CATATCGTGTCCAAACTCAGT-3' & 5'-ATAAACCCCCTGTGAAGTTGCA-3' \\
Collagen Type I & 5'-AACAGGAAGGGCCACGACAA-3' & 5'-GCGGCACAAGGGATTGAC-3' $^{\prime}$ \\
$\beta$-actin & 5'-TGACGTGGACATCCGCAAAG-3' $^{\prime}$ & 5'-CTGGAAGGTGGACAGCGAGG-3' $^{\prime}$ \\
\hline
\end{tabular}

\subsection{ELISA}

Collagen type I and IL-6, produced by osteoblast cells, were measured using ELISA. After treatments, culture media were collected and level of IL-6 was measured using Human IL-6 Quantikine ELISA Kit (R\&D system, Minneapolis, MN, USA). Levels of collagen type I were assessed using Procollagen-C ELISA kit (Metra Biosystems, Santa Clara, CA, USA).

\subsection{Nitric Oxide Assay}

Griess reaction was carried out to measure nitric oxide concentration in cell culture medium. In brief, culture medium of cell treated in presence or absence of TNF- $\alpha$, followed by incubation with adenine was collected and mixed with Griess reagent in a ratio of 1:1 and absorbance at $540 \mathrm{~nm}$ was measured. The concentration of nitrite was measured using sodium nitrite $\left(\mathrm{NaNO}_{2}\right)$ as a standard.

\subsection{Statistical Analysis}

The values were shown as means \pm SD. All results were analyzed by a one-way analysis of variance (ANOVA), incorporating with a Duncan multiple-comparison test. A $p$ values $<0.05$ indicated statistical significance.

Author Contributions: Conception and design: Y.-P.C., Y.-L.C., Y.-H.T., Y.W., C.-Y.K. and Y.-J.K.; Provision of study materials: Y.-L.C., Y.-H.T. and Y.W.; Collection and assembly of data: Y.-P.C., Y.-L.C., Y.-H.T. and Y.W.; Data analysis and interpretation: Y.-P.C., C.-Y.K. and Y.-J.K.; Manuscript writing: C.-Y.K. and Y.-J.K.; Final approval of manuscript: All authors. All authors have read and agreed to the published version of the manuscript.

Funding: This research received no external funding.

Conflicts of Interest: The authors declare no conflict of interest. 


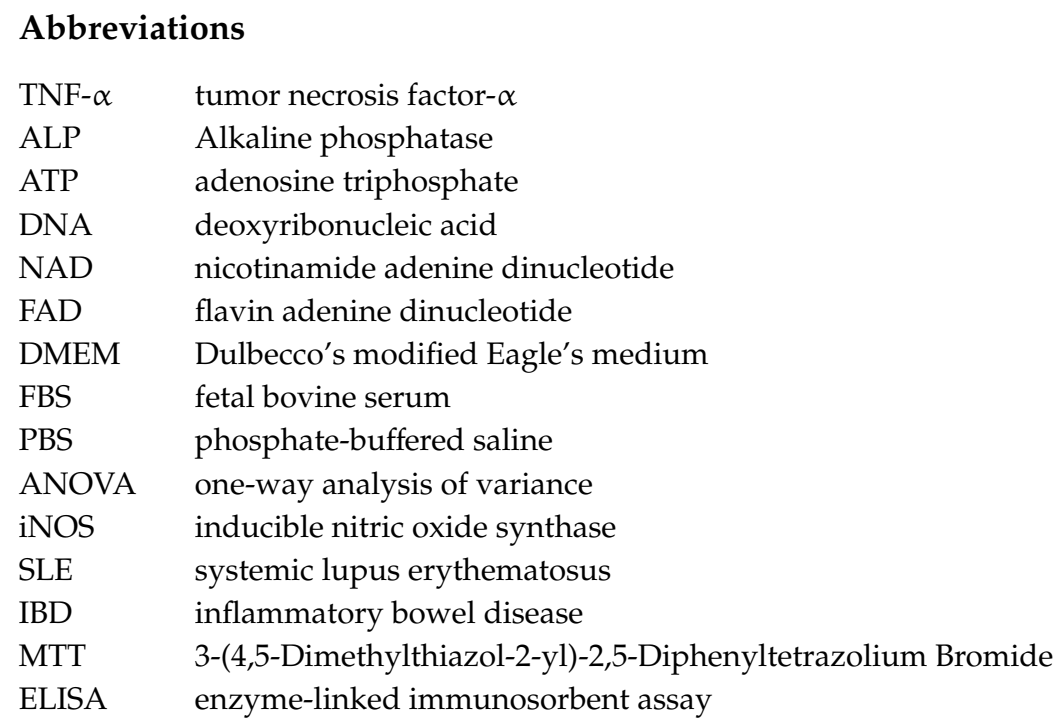

\section{References}

1. Johnell, O.; Kanis, J.A. An estimate of the worldwide prevalence and disability associated with osteoporotic fractures. Osteoporos. Int. 2006, 17, 1726-1733. [CrossRef] [PubMed]

2. Who are candidates for prevention and treatment for osteoporosis? Osteoporos. Int. 1997, 7, 1-6. [CrossRef] [PubMed]

3. Chandran, M.; Lau, T.C.; Gagnon-Arpin, I.; Dobrescu, A.; Li, W.; Leung, M.Y.M.; Patil, N.; Zhao, Z. The health and economic burden of osteoporotic fractures in Singapore and the potential impact of increasing treatment rates through more pharmacological options. Arch. Osteoporos. 2019, 14, 114. [CrossRef] [PubMed]

4. Borgstrom, F.; Sobocki, P.; Strom, O.; Jonsson, B. The societal burden of osteoporosis in Sweden. Bone 2007, 40, 1602-1609. [CrossRef]

5. Hernlund, E.; Svedbom, A.; Ivergard, M.; Compston, J.; Cooper, C.; Stenmark, J.; McCloskey, E.V.; Jonsson, B.; Kanis, J.A. Osteoporosis in the European Union: Medical management, epidemiology and economic burden. A report prepared in collaboration with the International Osteoporosis Foundation (IOF) and the European Federation of Pharmaceutical Industry Associations (EFPIA). Arch. Osteoporos. 2013, 8, 136. [CrossRef]

6. Wimalawansa, S.J. Prevention and treatment of osteoporosis: Efficacy of combination of hormone replacement therapy with other antiresorptive agents. J. Clin. Densitom. 2000, 3, 187-201. [CrossRef]

7. Schonberg, M.A.; Davis, R.B.; Wee, C.C. After the Women's Health Initiative: Decision making and trust of women taking hormone therapy. Women's Health Issues 2005, 15, 187-195. [CrossRef]

8. Green, J.; Czanner, G.; Reeves, G.; Watson, J.; Wise, L.; Beral, V. Oral bisphosphonates and risk of cancer of oesophagus, stomach, and colorectum: Case-control analysis within a UK primary care cohort. BMJ 2010, 341, c4444. [CrossRef]

9. Ginaldi, L.; Di Benedetto, M.C.; De Martinis, M. Osteoporosis, inflammation and ageing. Immun. Ageing 2005, 2, 14. [CrossRef]

10. Boyce, B.F.; Li, J.; Xing, L.; Yao, Z. Bone Remodeling and the Role of TRAF3 in Osteoclastic Bone Resorption. Front. Immunol. 2018, 9, 2263. [CrossRef]

11. Boyce, B.F.; Li, P.; Yao, Z.; Zhang, Q.; Badell, I.R.; Schwarz, E.M.; O’Keefe, R.J.; Xing, L. TNF-alpha and pathologic bone resorption. Keio J. Med. 2005, 54, 127-131. [CrossRef] [PubMed]

12. Blaschke, M.; Koepp, R.; Cortis, J.; Komrakova, M.; Schieker, M.; Hempel, U.; Siggelkow, H. IL-6, IL-1beta, and TNF-alpha only in combination influence the osteoporotic phenotype in Crohn's patients via bone formation and bone resorption. Adv. Clin. Exp. Med. 2018, 27, 45-56. [CrossRef]

13. Grassi, F.; Tell, G.; Robbie-Ryan, M.; Gao, Y.; Terauchi, M.; Yang, X.; Romanello, M.; Jones, D.P.; Weitzmann, M.N.; Pacifici, R. Oxidative stress causes bone loss in estrogen-deficient mice through enhanced bone marrow dendritic cell activation. Proc. Natl. Acad. Sci. USA 2007, 104, 15087-15092. [CrossRef] [PubMed] 
14. Zhu, S.; He, H.; Gao, C.; Luo, G.; Xie, Y.; Wang, H.; Tian, L.; Chen, X.; Yu, X.; He, C. Ovariectomy-induced bone loss in TNFalpha and IL6 gene knockout mice is regulated by different mechanisms. J. Mol. Endocrinol. 2018, 60, 185-198. [CrossRef] [PubMed]

15. Sidney, L.E.; Kirkham, G.R.; Buttery, L.D. Comparison of osteogenic differentiation of embryonic stem cells and primary osteoblasts revealed by responses to IL-1beta, TNF-alpha, and IFN-gamma. Stem Cells Dev. 2014, 23, 605-617. [CrossRef]

16. Fan, J.Z.; Yang, X.; Bi, Z.G. The effects of 6-gingerol on proliferation, differentiation, and maturation of osteoblast-like MG-63 cells. Braz. J. Med. Biol. Res. 2015, 48, 637-643. [CrossRef]

17. Centrella, M.; McCarthy, T.L.; Canalis, E. Tumor necrosis factor-alpha inhibits collagen synthesis and alkaline phosphatase activity independently of its effect on deoxyribonucleic acid synthesis in osteoblast-enriched bone cell cultures. Endocrinology 1988, 123, 1442-1448. [CrossRef]

18. Nazrun, A.S.; Norazlina, M.; Norliza, M.; Nirwana, S.I. The anti-inflammatory role of vitamin e in prevention of osteoporosis. Adv. Pharmacol. Sci. 2012, 2012, 142702. [CrossRef]

19. O'Connor, J.P.; Lysz, T. Celecoxib, NSAIDs and the skeleton. Drugs Today 2008, 44, 693-709. [CrossRef]

20. Rao, S.S.; Hu, Y.; Xie, P.L.; Cao, J.; Wang, Z.X.; Liu, J.H.; Yin, H.; Huang, J.; Tan, Y.J.; Luo, J.; et al. Omentin-1 prevents inflammation-induced osteoporosis by downregulating the pro-inflammatory cytokines. Bone Res. 2018, 6, 9. [CrossRef]

21. Yao, Z.; Lei, W.; Duan, R.; Li, Y.; Luo, L.; Boyce, B.F. RANKL cytokine enhances TNF-induced osteoclastogenesis independently of TNF receptor associated factor (TRAF) 6 by degrading TRAF3 in osteoclast precursors. J. Biol. Chem. 2017, 292, 10169-10179. [CrossRef] [PubMed]

22. Hosoi, T.; Ino, S.; Ohnishi, F.; Todoroki, K.; Yoshii, M.; Kakimoto, M.; Muller, C.E.; Ozawa, K. Mechanisms of the action of adenine on anti-allergic effects in mast cells. Immun. Inflamm. Dis. 2018, 6, 97-105. [CrossRef] [PubMed]

23. Silwal, P.; Shin, K.; Choi, S.; Kang, S.W.; Park, J.B.; Lee, H.J.; Koo, S.J.; Chung, K.H.; Namgung, U.; Lim, K.; et al. Adenine suppresses IgE-mediated mast cell activation. Mol. Immunol. 2015, 65, 242-249. [CrossRef]

24. Scioli, M.G.; Bielli, A.; Agostinelli, S.; Tarquini, C.; Arcuri, G.; Ferlosio, A.; Costanza, G.; Doldo, E.; Orlandi, A. Antioxidant treatment prevents serum deprivation- and TNF-alpha-induced endothelial dysfunction through the inhibition of NADPH oxidase 4 and the restoration of beta-oxidation. J. Vasc. Res. 2014, 51, 327-337. [CrossRef]

25. Silwal, P.; Lim, K.; Heo, J.Y.; Park, J.I.; Namgung, U.; Park, S.K. Adenine attenuates lipopolysaccharide-induced inflammatory reactions. Korean J. Physiol. Pharmacol. 2018, 22, 379-389. [CrossRef]

26. Watanabe, S.; Yoshimi, Y.; Ikekita, M. Neuroprotective effect of adenine on purkinje cell survival in rat cerebellar primary cultures. J. Neurosci. Res. 2003, 74, 754-759. [CrossRef] [PubMed]

27. Yoshimi, Y.; Watanabe, S.; Shinomiya, T.; Makino, A.; Toyoda, M.; Ikekita, M. Nucleobase adenine as a trophic factor acting on Purkinje cells. Brain Res. 2003, 991, 113-122. [CrossRef] [PubMed]

28. Luthje, J. Extracellular adenine compounds, red blood cells and haemostasis: Facts and hypotheses. Blut 1989, 59, 367-374. [CrossRef] [PubMed]

29. Saribal, D.; Hocaoglu-Emre, F.S.; Erdogan, S.; Bahtiyar, N.; Caglar Okur, S.; Mert, M. Inflammatory cytokines IL-6 and TNF-alpha in patients with hip fracture. Osteoporos. Int. 2019, 30, 1025-1031. [CrossRef]

30. Kastelan, D.; Kastelan, M.; Massari, L.P.; Korsic, M. Possible association of psoriasis and reduced bone mineral density due to increased TNF-alpha and IL-6 concentrations. Med. hypotheses 2006, 67, 1403-1405. [CrossRef]

31. Lee, W.Y.; Baek, K.H.; Rhee, E.J.; Tae, H.J.; Oh, K.W.; Kang, M.I.; Lee, K.W.; Kim, S.W.; Kim, C.C.; Oh, E.S. Impact of circulating bone-resorbing cytokines on the subsequent bone loss following bone marrow transplantation. Bone Marrow Transplant. 2004, 34, 89-94. [CrossRef] [PubMed]

32. Webb, S.J.; McPherson, J.R.; Pahan, K.; Koka, S. Regulation of TNF-alpha-induced IL-6 production in MG-63 human osteoblast-like cells. J. Dent. Res. 2002, 81, 17-22. [PubMed]

33. Confalone, E.; D'Alessio, G.; Furia, A. IL-6 Induction by TNFalpha and IL-1beta in an Osteoblast-Like Cell Line. Int. J. Biomed. Sci. 2010, 6, 135-140. [PubMed]

34. Abdel Meguid, M.H.; Hamad, Y.H.; Swilam, R.S.; Barakat, M.S. Relation of interleukin-6 in rheumatoid arthritis patients to systemic bone loss and structural bone damage. Rheumatol. Int. 2013, 33, 697-703. [CrossRef] [PubMed] 
35. Kriel, M.; Sayers, A.; Fraser, W.D.; Williams, A.M.; Koch, A.; Zacharowski, K.; Probert, C.S.; Tobias, J.H. IL-6 may modulate the skeletal response to glucocorticoids during exacerbations of inflammatory bowel disease. Calcif. Tissue Int. 2010, 86, 375-381. [CrossRef] [PubMed]

36. de Vries, T.J.; Yousovich, J.; Schoenmaker, T.; Scheres, N.; Everts, V. Tumor necrosis factor-alpha antagonist infliximab inhibits osteoclast formation of peripheral blood mononuclear cells but does not affect periodontal ligament fibroblast-mediated osteoclast formation. J. Periodontal Res. 2016, 51, 186-195. [CrossRef] [PubMed]

37. Timmen, M.; Hidding, H.; Wieskotter, B.; Baum, W.; Pap, T.; Raschke, M.J.; Schett, G.; Zwerina, J.; Stange, R. Influence of antiTNF-alpha antibody treatment on fracture healing under chronic inflammation. BMC Musculoskelet. Disord. 2014, 15, 184. [CrossRef]

38. Musacchio, E.; Valvason, C.; Botsios, C.; Ostuni, F.; Furlan, A.; Ramonda, R.; Modesti, V.; Sartori, L.; Punzi, L. The tumor necrosis factor-\{alpha\}-blocking agent infliximab inhibits interleukin 1beta (IL-1beta) and IL-6 gene expression in human osteoblastic cells. J. Rheumatol. 2009, 36, 1575-1579. [CrossRef]

39. Lin, S.K.; Kok, S.H.; Lin, L.D.; Wang, C.C.; Kuo, M.Y.; Lin, C.T.; Hsiao, M.; Hong, C.Y. Nitric oxide promotes the progression of periapical lesion via inducing macrophage and osteoblast apoptosis. Oral Microbiol. Immunol. 2007, 22, 24-29. [CrossRef]

40. Hukkanen, M.; Hughes, F.J.; Buttery, L.D.; Gross, S.S.; Evans, T.J.; Seddon, S.; Riveros-Moreno, V.; Macintyre, I.; Polak, J.M. Cytokine-stimulated expression of inducible nitric oxide synthase by mouse, rat, and human osteoblast-like cells and its functional role in osteoblast metabolic activity. Endocrinology 1995, 136, 5445-5453. [CrossRef]

41. Damoulis, P.D.; Hauschka, P.V. Nitric oxide acts in conjunction with proinflammatory cytokines to promote cell death in osteoblasts. J. Bone Miner. Res. 1997, 12, 412-422. [CrossRef] [PubMed]

42. Kalajzic, I.; Staal, A.; Yang, W.P.; Wu, Y.; Johnson, S.E.; Feyen, J.H.; Krueger, W.; Maye, P.; Yu, F.; Zhao, Y.; et al. Expression profile of osteoblast lineage at defined stages of differentiation. J. Biol. Chem. 2005, 280, 24618-24626. [CrossRef] [PubMed]

43. Chaturvedi, R.; Singha, P.K.; Dey, S. Water soluble bioactives of nacre mediate antioxidant activity and osteoblast differentiation. PloS ONE 2013, 8, e84584. [CrossRef]

44. Choi, J.Y.; Lee, B.H.; Song, K.B.; Park, R.W.; Kim, I.S.; Sohn, K.Y.; Jo, J.S.; Ryoo, H.M. Expression patterns of bone-related proteins during osteoblastic differentiation in MC3T3-E1 cells. J. Cell. Biochem. 1996, 61, 609-618. [CrossRef]

45. Manduca, P.; Sanguineti, C.; Pistone, M.; Boccignone, E.; Sanguineti, F.; Santolini, F.; Federici, A. Differential expression of alkaline phosphatase in clones of human osteoblast-like cells. J. Bone Miner. Res. 1993, 8 , 291-300. [CrossRef] [PubMed]

46. Gerstenfeld, L.C.; Chipman, S.D.; Kelly, C.M.; Hodgens, K.J.; Lee, D.D.; Landis, W.J. Collagen expression, ultrastructural assembly, and mineralization in cultures of chicken embryo osteoblasts. J. Cell Biol. 1988, 106, 979-989. [CrossRef]

(C) 2020 by the authors. Licensee MDPI, Basel, Switzerland. This article is an open access article distributed under the terms and conditions of the Creative Commons Attribution (CC BY) license (http://creativecommons.org/licenses/by/4.0/). 